\title{
De resterende 10 prosent håp. Om å holde seg i live - tross alt
}

\author{
Ved Kristin Ribe
}

\begin{abstract}
Jeg er bruker. Jeg har skada meg masse, mest med kutting, mye kutting og også farlig kutting, i tillegg til over 60 andre potensielt dødelige handlinger. Jeg har - veldig - villet dø. Men, jeg har også hatt et resthåp: Kanskje én dag (vil bli god). Kanskje ett menneske (kan like meg, kan hjelpe meg). Kanskje dette vonde kan gå over.
\end{abstract}

\section{Å vise seg som menneske}

Jeg begynte å tenke på døden som 14åring. Hørte på "The Final Cut” med Pink Floyd: "I held the blade in trembling hands, prepared to make it but, just then the phone rang. I never had the nerve to make the final cut." Og jeg tenkte, jeg må øve meg. Det å d $\varnothing$ er så skummelt, så vanskelig å få til - sangen viser hvor vanskelig det er å få til - at jeg må øve meg. Så jeg begynte å kutte meg. På leggen, på armene først, før jeg skulle prøve pulsåra. Men så skjedde det: Jeg oppdaga at det å se åpningen, det å kjenne at blodet kom ut, at det ga lettelse. Og kanskje, jeg tror det, har den oppdagelsen nettopp redda meg fra det døde. Jeg kunne kutte bort intensiteten i følelsene, og ikke minst: jeg ble såpass åpenbart trengende at noen grep inn. Når jeg ikke for noen pris, på noen måte kunne be om hjelp, med ord.

Jeg har villet d $\varnothing$ siden jeg var 14 . Jeg prøvde ikke på det før jeg var 24, men selv da, selv i det svarte, hadde jeg et lite håp, et resthåp. Jeg ville $\mathrm{d} \varnothing \mathrm{og}$ jeg ville leve. Men jeg kunne ikke leve uten hjelp. Men hvordan, hvordan kunne jeg be om hjelp, når jeg følte meg så verdiløs som menneske? Hvordan kunne jeg be om hjelp, når jeg forakta meg selv så veldig hvis jeg gjorde det? Svakhet. Jeg forakta det jeg så på som svakhet: $\AA$ trenge andre. Det er mange som nekter for at selvskadingen og intoxene er et "rop om hjelp", selv i all sin uendelige ensomhet (det å $\mathrm{d} \varnothing-$ kan noe være mer ensomt?). Men CASE-studien, der alle 15-16 åringer i Hedmark og Oppland ble spurt om de hadde skada seg og eventuelt om hvorfor, viste at svaralternativet "jeg ville rope om hjelp" var et av punktene med lavest score. Men. Jeg tror ikke det er representativt, jeg tror det er grovt underrapportert, det å trenge andre, ville ha andre inn. Men man skal liksom klare seg selv, ikke være til byrde.

Og igjen: Jeg kunne jo ikke innrømme at jeg "ropte om hjelp", da ville jeg være motbydelig svak, da ville jeg forakte meg selv enda mer. Og derfor kom jo også ytterligere kutting som følge av innleggelse, fordi jeg da ikke hadde vist meg sterk nok. Jeg trengte mange, mange innleggelser og samtaler til å kunne finne motsvar til denne tanken, erfaringer av at det å trenge andre ble sett på som fint, godt, at det ikke ble latterliggjort eller sett på som ynkelig.

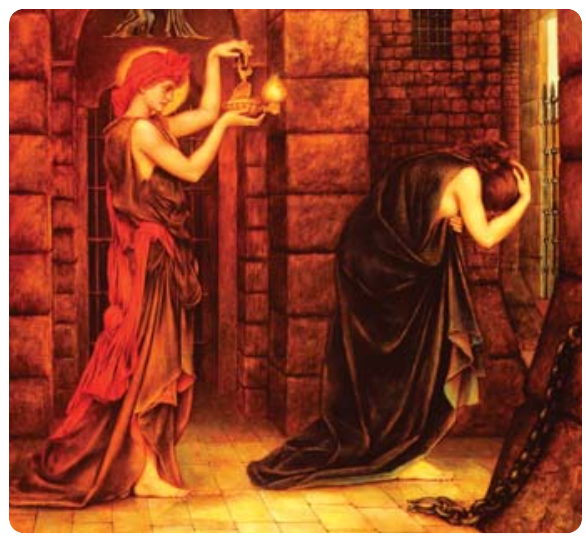

Evelyn de Morgan (1855-1919): Hope in a Prison of Despair

Og her må jeg si noe om manipulasjon. Mange kan sette denne merkelappen på slik død-nær og/eller selvskadende adferd. Men det er ikke manipulasjon, det er en fortvilt bønn, ikke et krav til omgivelsene, men en bønn som jeg ikke greide å si, med ord. Jeg klarte ikke gråte: I tårekanalene var det tomt. (Så tomt at jeg trodde noe var galt med dem, hadde det ikke vært for at de virka når jeg sykla i motvind.) Og jeg klarte ikke be om hjelp til meg selv: Det hadde jeg aldri gjort. Og jeg tenker, med en viss aggresjon:

Hvis noen mener det er manipulasjon å be om hjelp ved kutting eller ved selvmordsfors $\varnothing \mathrm{k}$ : Pr $\varnothing v$ selv, så kan du kalle det manipulasjon hvis - og bare hvis - du etter 50 fors $\varnothing \mathrm{k}$ synes det er en effektiv metode. Og jeg tenker: Hvis siste 10 prosent håp til omverdenen er å kutte seg og legge seg i veibanen og enten bli påkjørt og drept eller bli ført bort av politi under banning fra bilistene involvert er ikke det likevel bedre, enn å ha 0 prosent håp og gå og henge seg? Hvem kan si, at slike desperate handlinger er gale? Slik jeg ser det, handler det om å ha valg versus å ikke ha valg. Jeg tok overdoser som en bønn til verden, jeg så det som en siste utvei, en siste sjanse. Jeg hadde et håp, tross alt. $\AA$ ikke se noen utvei, å ikke ha noe resthåp - er ikke det selve selvmordets forstyrrelse?

\section{Å nærme seg det døde}

Jeg har tatt mange overdoser. Noen ganger med ganske ufarlige piller, der jeg etter hvert lærte at jeg med stor sannsynlighet kom til å våkne igjen. Men jeg lengta sånn etter å d $\varnothing$ at jeg tok dem, bare for - i pillenes bevisstl $\varnothing$ shet og s $\varnothing \mathrm{vn}$ - å likne det d $\varnothing$ de. Å nærme seg det d $\varnothing$ de var godt for meg. Da følte jeg endelig, at jeg hadde vært ekte, hvor rart det enn kan høres. Men jeg drev også med ganske omfattende hasard: Jeg var, med både handlinger og ukjente piller villig til å ta sjansen på hvilket utfall som helst. Jeg ville så gjerne $\mathrm{d} \phi$, selv om jeg også ville leve, at jeg lot tilfeldighetene råde. Jeg tenkte: Jeg greier ikke bestemme meg, jeg lar andre avgjøre, redde meg, hvis de vil, hvis de kommer i tide. Jeg er ikke redd for å være $\mathrm{d} \varnothing \mathrm{d}$. Jeg tror på en god død, i omsorg hos gud. Men jeg er redd for overgangen. Det å d $\varnothing$ sånn aleine er så veldig, så utrolig ensomt. Og bare det sier jo noe om at jeg gjerne vil til menneskene, vil være i, ikke bare hos. Jeg vil at noen skal være glad for at jeg finnes. Høyest på фnskelista mi var lenge: å d $\varnothing$. Men d $\varnothing$ på en sånn måte at de jeg er glad i ikke blei såra. Nest фverst på ønskelista: at jeg skal kunne merke, kjenne i meg, at noen vil jeg skal leve. Håpet er: at de to en dag skal bytte plass.

Og her, i håpet og i håpløsheten, vil jeg fors $\varnothing$ ke å si noe om tvang. Jeg har vært glad for at jeg noen ganger (i begynnelsen) ble sendt på tvang inn på 
psykiatrisk. Jeg trengte det. For å kunne få anledning til å roe det vonde ned litt og for å kunne gjenopprette tilliten til sykehuset og personalet, reparere den følelsen av avvisning fra forrige innleggelse som gjorde at jeg sa nei til hjelp. Men overlegen min var klar: Vi kan ikke ha henne på tvang, ikke enda en gang frata henne retten til å selv snakke for seg, ikke enda en gang frata henne stemme. Hvis jeg sa nei til innleggelse og hjelp, skulle det respekteres. Det er så enormt skadelig, mente min overlege, det å ikke kunne innrømme at man trenger andre, det å ikke kunne be om hjelp, det å ikke bruke stemmen. Men det er i tillegg veldig skadelig, tenker jeg, det å kjenne hjelpen som "dette er bare noe vi må, ikke noe som vi vil" - slik som tvangsinnleggelser kan kjennes ut som. Ved bruk av tvang er det liksom bare regler og forskrifter for at hjelpen blir gitt meg, og ikke nødvendigvis en genuin vilje til å hjelpe meg. Men når jeg så har blitt innlagt, sagt ja til innleggelse, mener jeg det må få et motsvar, det Skårderud ved flere innlegg jeg har lest poengterer omkring å vente med praten til "alt har roa seg litt ned", og ikke når pasienten er for ustabil, oppspilt og urimelig. Man skal smi mens jernet er lunka, skriver Skårderud. Selv tenker jeg til dette: Nei! Det er godt å være litt urimelig, det er godt å ikke ta hensyn, det er godt å bare velte ting ut av seg uten å måtte være fornuftig i alt. Det er jo nettopp fornuften og sperrene som alltid har stengt følelsene mine av - og så skal jeg fortsette med det? Med faglig begrunnelse: Det er det beste for meg? Nei, nei, nei! Jeg trengte å få det dypeste, voldsomste ut, jeg trengte å å få et forhold til det, lære det å kjenne FØR jeg kunne lære å regulere det. Hvordan skulle jeg ellers vite hva jeg skulle regulere? Hvordan skulle jeg ellers få et håp, om at jeg, om at mine følelser, er til å bære? (Hvis vi kan holde dem ut, så kanskje kan du det en dag også.) $O g$ ja, jeg trengte mer kontroll over impulsene. Men jeg forsto jo ikke hvorfor jeg gjorde mye av dette, hvis jeg ikke tok fram følelsene, så dem, sånn de virkelig var rett før og rett etter kutting og suicidaladferd. Og jeg tenker: Først gjenkjenne følelser, så vedkjenne seg følelser, og så, først så kan man lære å mestre på en annen måte. Jeg følte meg så enormt ærlig når jeg snakka sånn, helt ute av meg, og jeg kjente: Dette er meg. Dette er også meg. Og det var fint, på et vis.

Og så tenker jeg at det er virkelig viktig det å $\varnothing$ ke bevisstheten omkring merkelappen "kronisk suicidal": Ser dere ikke, at det tar fra meg håp? Kronisk betyr til evig tid, uhelbredelig. Jeg tenkte: Jeg kommer aldri til å komme ut av selvskadingen og selvmordstrangen, annet enn ved å d $\varnothing$. Jeg kan like godt $\mathrm{d} \varnothing$ først som sist, det er ikke håp likevel, det vonde vil bare fortsette og fortsette. Jeg tenker at det å heller si "langvarig suicidal" gir meg et helt annet håp, helt andre krefter. Det er ikke likegyldig for meg hvilket ord som brukes.

\section{Å ha noe å ville}

I starten klynget jeg meg til hjelpen, jeg

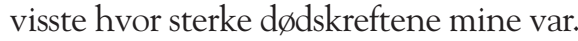
Og så ble det utskrivelser, nesten umenneskelige utskrivelser, men jeg ser det nå: Jeg måtte det. Jeg måtte ut, måtte lære å kjenne livet som noe annet enn bare vondt. Ha gode opplevelser, også. Kanskje var det mange ganger på grensa til sterkt uforsvarlig å skrive meg ut. Og etter hvert ble det lettere og lettere for meg å prøve å $\mathrm{d} \varnothing$, jeg hadde gjort det før, så det var ikke lenger fullt så skummelt, så høy terskel. Og jeg hadde jo så vondt lenge prøvd å gi hjelperne en sjanse, gitt livet en sjanse. Men så falt jeg jo stadig, stadig tilbake i motløsheten. Og så tenker jeg: Hvor uendelig viktig har det vel ikke vært for meg, i dette, i denne kampen om livet, å ha noe jeg ville, ha noe eller noen å komme tilbake til etter en innleggelse, noe å holde ut for. Noe jeg kan finne glede av, noe jeg kan føle stolthet over. Resthåpet mitt har vært: Minst én person som jeg betyr noe for. Minst én ting til jeg har lyst til å gjøre. Da jeg ble innlagt første gangen, hadde jeg 19 dager igjen å leve, datoen for selvmordet var satt. Jeg tenkte: Dette er nok. Dette er så langt jeg kommer. Men så var det en ekstravakt der som tok tak i det jeg sist hadde gitt slipp på: lesinga, litteraturen. Han leste en bok han hadde fătt vite jeg likte en kveld han hadde fri - og kom tilbake på jobb og vi snakka om den. Det var så fint. Nesten all glede var stengt i meg, borte fra meg, men han fant den siste lille fliken som var igjen og tok tak i den, gjorde den viktig. Og gjorde ved det resthåpet og restviljen min litt sterkere.

\section{Bonus}

Selvmordshandlinger for meg har vært en slags følge av overbevisning om at: Jeg orker ikke. Jeg må bort, dette går ikke. Noen ganger må jeg konsentrere meg, legge alle krefter inn på bare det, å holde ut, holde meg i live. Andre ganger går det lettere. Men jeg er 38 år. Jeg har villet dø i 24 år, og jeg merker at de kommer så lett, de tankene. Og så blir jeg redd: Selvmordstankene kan ha "grodd fast", kanskje jeg aldri kan bli kvitt dem helt, selv om jeg nå har det bedre. Men kanskje jeg ikke trenger å være ulidelig redd likevel: Jeg kan la være å handle i henhold til disse tankene. Og det trøster faktisk litt. Jeg kan bestemme. Og jeg vil mer leve nå, det er ikke like vondt. Og faktisk tenker jeg jo at livet mitt nå er ren bonus. Jeg skulle ha dødd ved mange anledninger, men jeg lever. Tre ganger hadde jeg bare 2 prosent resthåp, det var virkelig nære på. Andre ganger var det nære på fordi jeg ikke kjente konsekvensene. Og jeg tenker, jeg skulle ikke ha levd nå, egentlig skulle jeg ikke ha levd. Det fine jeg opplever nå skulle jeg - om jeg hadde gitt etter for 98 prosents motløshet - ikke ha opplevd. Det er bonusen min for å ha holdt ut.

Jeg har trengt håpet. Jeg har trengt at hjelperne mine styrka det friske i meg. At de styrka det som ville leve, om det var aldri så svakt. Jeg har fått slik hjelp.

Og likevel er det vanskelig.

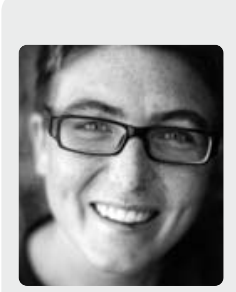

Kristin Ribe (f. 1972) har hovedfag i nordisk litteratur. Hun utga i 2007 , basert på egne opplevelser fra over 13 år med alvorlig selvskading, fagboka Selvskadingens dynamikk (Universitetsforlaget) sammen med psykolog og stipendiat Anita Moe. Hun har også utgitt romanene Forsnakkelser (2003), Drikke det vannet som ormene hadde ligget $i$ (2006), VÅKE (Håret gråter jeg i) (2008) og Syn (2010), alle Forlaget Oktober.

kristin_ribe@hotmail.com 